\title{
PENINGKATAN HASIL BELAJAR PENDIDIKAN AGAMA ISLAM MAHASISWA MELALUI KOMPETENSI PROFESIONAL DOSEN DAN MINAT BELAJAR MAHASISWA
}

\author{
ROBIATUL ADAWIYAH \\ Madrasah Ibtidaiyah Negeri 3 Kota Tangerang Selatan \\ robiatul240@gmail.com
}

\begin{abstract}
ABSTRAK
Hasil belajar merupakan perolehan nilai yang dicapai setelah melalui proses kegiatan belajar mengajar. Setiap kegiatan pembelajaran tentunya selalu mengharapkan akan menghasilkan pembelajaran yang maksimal sehingga dapat mencetak lulusan yang berkualitas. Lulusan yang berkualitas juga menentukan kualitas perguruan itu sendiri, sebab tidak hanya memperbanyak sarjana, namun juga sarjana yang berkualitas, sarjana yang mampu bertahan hidup, dalam arti memiliki penghasilan yang dapat digunakan untuk menghidupi dirinya dan keluarganya, sesuai dengan keahlian yang diperoleh pada masa kuliah. Dalam hal ini kualitas seorang mahasiswa ketika lulus terlihat dari pencapaian hasil belajar yang diperolehnya semasa kuliah. Namun faktanya tidak semua mahasiswa dapat menjadi lulusan yang berkualitas. Ada beberapa faktor yang mempengaruhi hasil belajar, kemampuan pedagogik dan professional dosen sebagai pengajar juga menjadi faktor penentu keberhasilan dalam pembelajaran. Menurut Farida Sarimaya, kemampuan pedagogik meliputi "pemahaman terhadap peserta didik, perencanaan dan pelaksanaan pembelajaran, serta evaluasi prestasi belajar". Salah satu kompetensi pedagogik pengajar adalah mengelola proses pembelajaran. Apabila ada dosen yang kurang mampu mengelola proses pembelajaran, sehingga proses perkuliahan menjadi tidak menarik. Eksistensi Pendidikan Agama (termasuk Pendidikan Agama Islam atau PAl) di Perguruan Tinggi Umum di samping merupakan mata kuliah yang wajib diambil oleh mahasiswa, juga sangat berarti untuk mewujudkan tercapainya tujuan pendidikan seperti yang digariskan oleh Sistem Pendidikan Nasional. yaitu manusia yang beriman dan bertaqwa kepada Tuhan Yang Maha Esa serta berbudi pekerti luhur. Dosen merupakan bagian dari tenaga pendidik dan kependidikan yang mengemban tugas sebagai salah faktor penentu untuk mencapai tujuan dan meningkatkan mutu pendidikan suatu sekolah atau lembaga pendidikan, karena seorang guru/dosen akan berhubungan langsung dengan para siswa atau peserta didik, untuk membantu atau memberi bantuan yang pada akhirnya akan menghasilkan alumni atau lulusan (output) sesuai dengan visi dan misi yang diharapkan. Oleh karena itu diperlukan manajemen tenaga kependidikan yang baik dan professional.
\end{abstract}




\begin{abstract}
Learning outcomes are the acquisition of values achieved after going through the process of teaching and learning activities. Each learning activity certainly always expects to produce maximum learning so that it can produce quality graduates. Qualified graduates also determine the quality of the college itself, because it does not only increase the number of graduates, but also qualified graduates, graduates who are able to survive, in the sense of having income that can be used to support themselves and their families, in accordance with the expertise gained during college. In this case the quality of a student when graduating can be seen from the achievement of learning outcomes obtained during college. But the fact is that not all students can become quality graduates. There are several factors that affect learning outcomes, pedagogical abilities and professional lecturers as instructors are also critical success factors in learning. According to Farida Sarimaya, pedagogical abilities include "understanding students, planning and implementing learning, and evaluating learning achievement". One of the instructors' pedagogical competencies is managing the learning process. If there are lecturers who are less able to manage the learning process, so the lecture process becomes unattractive. The existence of Religious Education (including Islamic Religious Education or PAl) in General Higher Education in addition to being a subject that must be taken by students, is also very meaningful to realize the achievement of educational goals as outlined by the National Education System. namely people who believe and devote to God Almighty and virtuous character. Lecturers are part of the teaching and educational staff who carry out the task as one of the determining factors to achieve goals and improve the quality of education of a school or educational institution, because a teacher / lecturer will deal directly with students or students, to help or provide assistance to eventually will produce alumni or graduates (output) in accordance with the vision and mission expected. Therefore we need a good and professional management

staff.
\end{abstract}

Keywords: PAI Learning Outcomes and Professional Competence of Lecturers 


\section{A. PENDAHULUAN}

Pendidikan adalah usaha sadar dalam membentuk anak didik untuk mencapai perkembangannya menuju kedewasaan jasmani maupun rohani. Melalui pendidikan manusia dididik, dibina dan dikembangkan segala potensipotensinya. Hal ini dilakukan dengan tujuan agar menjadikan anak didik sebagai manusia yang berkualitas, bertanggungjawab dan berakhlak mulia. Sebagaimana yang tercantum dalam UU RI No. 20 tahun 2003 tentang sistem Pendidikan Nasional Bab II, Pasal 3 yang berbunyi: Pendidikan Nasional berfungsi mengembangkan kemampuan dan membentuk watak serta peradaban bangsa yang bermartabat dalam rangka mencerdaskan kehidupan bangsa, bertujuan untuk berkembangnya potensi peserta didik agar menjadi manusia yang beriman dan bertakwa kepada Tuhan Yang Maha Esa, berakhlak mulia, sehat, berilmu, cakap, kreatif, mandiri, dan menjadi warga negara yang demokratis serta bertanggungjawab. ${ }^{1}$

Pendidikan Nasional berdasarkan atas Pancasila dan bertujuan untuk meningkatkan ketakwaan terhadap Tuhan Yang Maha Esa, kecerdasan, keterampilan, mempertinggi budi pekerti, memperkuat kepribadian dan mempertebal semangat kebangsaan agar menumbuhkan manusia-manusia pembangunan yang membangun dirinya sendiri serta bersama-sama bertanggung jawab atas pembangunan bangsa.

Dunia pendidikan tentunya tidak terlepas dari kegiatan belajar mengajar dan juga kegiatan mendidik, belajar mengajar merupakan suatu interaksi atau hubungan timbal balik antara guru/dosen dan peserta didik. Sehingga dalam proses belajar mengajar dijadikan sebagai tolak ukur dalam keberhasilan belajar peserta didik, bukan hanya hasil belajar secara umum yang di harapkan dalam memperoleh peningkatan namun dari segi kepribadian dan kemampuan yang diperlukan untuk membentuk output pembelajaran sekaligus pendidikan ideal.

Pendidikan merupakan unsur terpenting dalam mewujudkan manusia seutuhnya. Maju mundurnya gerak dan kepribadian suatu bangsa, kini ataupun masa yang akan datang sangat ditentukan oleh pendidikan. Pendidikan memegang peran penting dalam pembangunan masa depan, yaitu dengan membangun sumber daya manusia agar dapat menjadi subyek pembangunan yang poduktif.

Sumber daya manusia yang bermutu dapat dihasilkan melalui lembaga pendidikan yang bermutu pula. Mutu pendidikan dapat berupa hasil belajar yang didalamnya terdapat aspek kognitif, afektif, dan psikomotorik. Yang dimaksud dengan lembaga pendidikan yang bermutu ialah lembaga pendidikan dimana terdapat suasana pendidikan yang kondusif, proses belajar mengajar, kurikulum yang relevan, sumber-sumber belajar, fasilitas belajar, serta

${ }^{1}$ Undang-undang Sisdiknas Sistem Pendidikan Nasional, Jakarta: Sinar Grafika, 2003, hlm.56. 
pengelolaan yang baik terutama tenaga pendidik (guru/dosen) yang professional.

Misi pendidikan yang mempunyai kaitan dengan kompetensi dosen adalah upaya mencerdaskan kehidupan bangsa dan mengembangkan kualitas manusia. Pengembangan kompetensi dan kualitas dosen merupakan suatu keharusan agar dosen mampu mempersiapkan generasi muda dalam menghadapi masa depannya.

Kemampuan profesional dapat diartikan suatu bagian dari kompetensi dosen. Ia dituntut agar mempunyai wawasan yang luas di bidangnya agar mampu berinovasi untuk memperbaiki pembelajaran. Kompetensi profesional ini dicapai melalui penelaahan yang relevan dan studi-studi yang luas serta mendalam dalam bidang ilmu keahlian dosen. ${ }^{2}$ Oleh karena itu, salah satu upaya untuk meningkatkan mutu pendidikan dibutuhkan adanya tenaga-tenaga pengajar yang mempunyai kompetensi profesional. Sebab, kompetensi dosen berpengaruh langsung terhadap hasil belajar subjek didik. Begitu juga dengan pendidikan agama yang diberikan oleh dosen yang memiliki kompetensi profesional baik akan memberi pengaruh besar terhadap pemahaman ajaran agama subjek didik.

Pendidikan Agama Islam merupakan hal yang sangat utama karena dalam rangka mempersiapkan mahasiswa yang percaya dan taat kepada Allah Swt, berkepribadian yang baik dan yang mampu menerapkan nilai-nilai moral Islam di seluruh aspek kehidupan seperti dalam kehidupan pribadi, keluarga, masyarakat nasional dan bernegara.

Pendidikan agama merupakan pondasi utama bagi manusia, karena banyak manfaat yang bisa kita raih dalam mempelajari ilmu agama. Pertama, dapat menumbuhkan jiwa keberanian dalam menegakan kebenaran dan rasa takut melakukan perbuatan yang keliru. Kedua, menumbuhkan sifat dewasa dalam menghadapi persoalan kehidupan terlebih ketika kita ditimpa musibah, akan lebih arif dan bijak dalam menyelesaikanya. Ketiga bersikap sederhana dan patuh terhadap aturan.

Tulang punggung bangsa ini ada dipundak generasi pemuda, negara Indonesia tidak akan maju bila generasi mudanya lemah dan kurang kesadaran akan pentingnya pendidikan agama islam. Sekarang, akankah kita membiarkan generasi muda lebih buruk dari sebelumnya atau kita hanya menonton generasi ini tergerus oleh perilaku buruk. Mari kita selamatkan generasi muda kita dengan pendidikan agama islam.

Pendidikan Agama Islam diharapkan mampu menghasilkan manusia yang selalu berupaya menyempurnakan iman, takwa, dan berakhlak mulia, akhlak mulia mencakup etika, budi pekerti, atau moral sebagai perwujudan dari pendidikan.Manusia seperti itu diharapkan tangguh dalam menghadapi

2 Jamal Ma`mur Asmani, 7 Kompetisi Guru Menyenangkan dan Profesional, Yogyakarta: Power Books, 2009, hlm. 7. 
tantangan, hambatan, dan perubahan yang muncul dalam pergaulan masyarakat baik dalam lingkup lokal, nasional, regional maupun global.

Pendidikan agama merupakan salah satu materi yang bertujuan meningkatkan akhlak mulia serta nilai-nilai spiritual dalam diri anak. Hal ini menunjukkan bahwa pendidikan agama mempunyai peranan yang penting dalam melaksanakan pendidikan karakter di sekolah atau di kampus. Oleh karena itu Pendidikan agama menjadi salah satu mata pelajaran wajib baik dari sekolah tingkat dasar, menengah dan perguruan tinggi. Maka sekolah harus mampu menyelenggarakan pendidikan agama secara optimal dengan cara mengaplikasikan nilai-nilai agama dalam lingkungan sekolah yang dilakukan oleh seluruh guru atau dosen dan peserta didik secara bersama-sama serta berkesinambungan. Hal yang juga sangat menarik jika sekolah mampu menyusun kurikulum dengan menerapkan nilai-nilai agama yang tercermin dalam setiap mata pelajaran, Pada dasarnya pendidikan agama menitik beratkan pada penanaman sikap dan kepribadian berlandaskan ajaran agama dalam seluruh sendi-sendi kehidupan mahasiswa kelak.

Pendidikan Agama Islam (PAI) adalah salah satu pelajaran yang diajarkan di perguruan tinggi umum kepada mahasiswa-mahasiswi yang beragama Islam. Sejak tahun 1966, usaha pembinaan Pendidikan Agama Islam adalah berdasarkan Ketetapan MPRS Nomor XXVII/MPRS/1966 yang berbunyi: ${ }^{3 \prime}$ menetapkan pendidikan agama menjadi mata pelajaran di sekolahsekolah mulai dari Sekolah Dasar sampai dengan Universitas Negeri”.

Mata kuliah Pendidikan Agama pada perguruan tinggi termasuk ke dalam kelompok MKU (Mata Kuliah Umum) yaitu kelompok mata kuliah yang menunjang pembentukan kepribadian dan sikap sebagai bekal mahasiswa memasuki kehidupan bermasyarakat. Mata kuliah ini merupakan pendamping bagi mahasiswa agar bertumbuh dan kokoh dalam moral dan karakter agamisnya sehingga ia dapat berkembang menjadi cendekiawan yang tinggi moralnya dalam mewujudkan keberadaannya di tengah masyarakat.

Tujuan mata kuliah Pendidikan Agama pada Perguruan Tinggi ini amat sesuai dengan dasar dan tujuan pendidikan nasional dan pembangunan nasional. GBHN (Garis Besar Haluan Negara 1988) menggariskan bahwa pendidikan nasional yang berdasarkan Pancasila "bertujuan untuk meningkatkan kualitas manusia Indonesia, yaitu manusia yang beriman dan bertakwa terhadap Tuhan Yang Maha Esa, berbudi pekerti luhur, berkepribadian, berdisiplin, bekerja keras, bertanggung jawab, mandiri, cerdas, terampil serta sehat jasmani dan rohani, dengan demikian pendidikan nasional akan membangun dirinya sendiri serta bersama-sama bertanggung jawab atas pembangunan bangsa".

3Timur Djaelani, Kebijaksanaan Pembinaan Kelembagaan Agama Islam, Jakarta: Darma Bhakti, 1983, vol.1, hlm. 26. 
Kualitas manusia yang ingin dicapai adalah kualitas seutuhnya yang mencakup tidak hanya aspek rasio, intelek atau akal budinya dan aspek fisik atau jasmaninya, tetapi juga aspek psikis atau mentalnya, aspek sosial yaitu dalam hubungannya dengan sesama manusia lain dalam masyarakat dan lingkungannya, serta aspek spiritual yaitu dalam hubungannya dengan Tuhan Yang Maha Esa, Sang Pencipta. Pendidikan Tinggi merupakan arasy tertinggi dalam keseluruhan usaha pendidikan nasional dengan tujuan menghasilkan sarjana-sarjana yang profesional, yang bukan saja berpengetahuan luas dan ahli serta terampil dalam bidangnya, serta kritis, kreatif dan inovatif, tetapi juga beriman dan bertaqwa kepada Tuhan yang Maha Esa, berkepribadian nasional yang kuat, berdedikasi tinggi, mandiri dalam sikap hidup dan pengembangan dirinya, memiliki rasa solidaritas sosial yang tangguh dan berwawasan lingkungan.

Tugas guru atau dosen yang utama mengajar dan mendidik mahasiswa, di dalam kelas maupun di luar kelas, maka dari itu, seorang dosen mempunyai tugas yang sangat mulia, yaitu guru dan dosen sebagai pendidik, dosen sabagai pengajar, dosen sebagai pejuang akademik, guru/dosen sebagai duta ilmu pengetahuan dan guru/dosen sebagai pencerdas bangsa menyampaikan pengetahuan dan keterampilan, serta mengembangkan sikap. Pengetahuan dan teknologi selalu berkembang, bahkan sangat cepat dosen harus memahami perkembangan pengetahuan dan teknologi itu dengan belajar dari beragam media yang tersedia di lingkungannya, sehingga kemampuannya berkembang sesuai tuntunan zaman.

Namun dalam kenyataannya kebanyakan mahasiswa belum semuanya memprioritaskan pelajaran agama, mereka lebih memprioritaskan pelajaran umum atau pelajaran yang sesuai jurusan mereka semata. Hal ini dapat dilihat dari hasil belajar mahasiswa saat Ujian Tengah Semester (UTS) yang menunjukkan ada beberapa mahasiswa yang mendapatkan nilai di bawah 70 . Padahal yang diharapkan dosen Pendidikan Agama Islam adalah mahasiswa minimal mendapatkan nilai 70 saat Ujian Tengah Semester.

Hasil belajar PAI mahasiswa rendah salah satunya disebabkan mahasiswa mengesampingkan pelajaran agama, mereka mengikuti pelajaran agama hanya sebatas formalitas saja. Sedangkan persyaratan akademik di pendidikan tinggi bukan sekedar mengikuti perkuliahan saja, tetapi ada ketentuan-ketentuan lain seperti presentase kehadiran dalam perkuliahan, penyelesaian tugas-tugas, dan ikut aktif dalam kegiatan akademik lainnya (diskusi, presentasi, mengkuti ujian, kuis). Keberhasilan mahasiswa dalam bidang akademik ditandai dengan prestasi akademik yang dicapai, ditunjukkan melalui Indeks Prestasi (IP) maupun indeks Prestasi Kumulatif serta ketepatan dalam menyelesaikan studi.

Berdasarkan fakta yang terjadi dalam dalam salah satu penelitian yang menyatakan bahwa "Mutu pendidikan khususnya tingkat prestasi belajar atau hasil belajar selalu menjadi bahan pembicaraan dari berbagai kalangan, baik 
birokrat, pemerhati, pengelola penyelenggara pendidikan, maupun dari kalangan dosen. Perlu diketahui bahwa kualitas pendidikan di Indonesia masih sangatlah memprihatinkan dapat dikatakan juga bahwa prestasi Indonesia masih rendah. Ini dibuktikan antara lain dari data UNESCO (2012) tentang peringkat Indeks Pengembangan Manusia, yaitu komposisi dari peringkat pencapaian pendidikan, kesehatan, dan penghasilan per kepala keluarga yang menunjukkan bahwa indeks pengembangan manusia Indonesia makin menurun. Di antara 174 negara di dunia, Indonesia menempati urutan ke-109 (2012). Menurut survei Political and Economic Risk Consultant (PERC), kualitas pendidikan di Indonesia berada pada urutan ke-12 dari 12 negara di Asia. Posisi Indonesia berada di bawah Vietnam.

Eksistensi Pendidikan Agama (termasuk Pendidikan Agama Islam atau PAl) diPerguruan Tinggi Umum di samping merupakan mata kuliah yang wajib diambil oleh mahasiswa, juga sangat berarti untuk mewujudkan tercapainya tujuan pendidikan seperti yang digariskan oleh Sistem Pendidikan Nasional. yaitu manusia yang beriman dan bertaqwa kepada Tuhan Yang Maha Esa serta berbudi pekerti luhur.

Dosen merupakan bagian dari tenaga pendidik dan kependidikan yang mengemban tugas sebagai salah faktor penentu untuk mencapai tujuan dan meningkatkan mutu pendidikan suatu sekolah atau lembaga pendidikan, karena seorang guru/dosen akan berhubungan langsung dengan para siswa atau peserta didik, untuk membantu atau memberi bantuan yang pada akhirnya akan menghasilkan alumni atau lulusan (output) sesuai dengan visi dan misi yang diharapkan. Oleh karena itu diperlukan manajemen tenaga kependidikan yang baik dan professional.

Proses belajar dan hasil belajar siswa bukan saja ditentukan oleh sekolah, pola, struktur, dan isi kurikulum, akan tetapi sebagian besar oleh kompetensi guru yang mengajar dan membimbing mereka. Oemar Hamalik menyatakan bahwa "guru yang memilki kompetensi akan lebih mampu menciptakan lingkungan belajar yang efektif, menyenangkan, dan akan lebih mampu mengelola kelas, sehingga belajar peserta didik bisa optimal." ${ }^{4}$

Proses pendidikan diawali ketika individu dilahirkan dalam lingkungan keluarga kemudian dilanjutkan dan dikembangkan melalui jenjang pendidikan formal, terstruktur dan sistematis dalam lingkungan sekolah. Di lingkungan kampus terjadi interaksi secara langsung antara mahasiswa sebagai peserta didik dan dosen sebagai pendidik dalam suatu proses pembelajaran. Melalui perguruan tinggi, mahasiswa tidak hanya diberikan pemahaman tentang ilmu pengetahuan, tetapi juga pemahaman moral dan keagamaan. Namun pendidikan tidak hanya menjadi tanggung jawab sekolah ataupun perguruan tinggi, akan tetapi keluarga dan masyarakat juga ikut bertanggung jawab.

${ }^{4}$ Oemar Hamalik, Kurikulum dan Pembelajaran, Jakarta: Bumi Aksara, 2009, hlm. 36. 
Untuk dapat menciptakan sumber daya manusia yang berkualitas maka sebagai penyelenggara dalam jajaran tertinggi pendidikan formal dalam hal ini adalah perguruan tinggi dengan peserta didik yaitu mahasiswa dan tenaga pengajar yaitu dosen merupakan tempat pembentukkan sumber daya manusia yang diharapkan mampu menghasilkan lulusan yang memadai dalam penguasaan, pengembangan serta menemukan terobosan di bidang pengetahuan dan teknologi.

Namun berhasil atau tidaknya pencapaian tujuan pendidikan tersebut banyak bergantung kepada keberhasilan proses pembelajaran salah satu tolak ukurnya yang digunakan adalah hasil belajar yang mengacu pada pencapaian taksonomi pendidikan yang mencakup aspek kognitif, afektif, dan psikomotorik.

Terkait dengan hasil belajar, bahwa hasil belajar merupakan perolehan nilai yang dicapai setelah melalui proses kegiatan belajar mengajar. Setiap kegiatan pembelajaran tentunya selalu mengharapkan akan menghasilkan pembelajaran yang maksimal sehingga dapat mencetak lulusan yang berkualitas. Lulusan yang berkualitas juga menentukan kualitas perguruan itu sendiri, sebab tidak hanya memperbanyak sarjana, namun juga sarjana yang berkualitas, sarjana yang mampu bertahan hidup, dalam arti memiliki penghasilan yang dapat digunakan untuk menghidupi dirinya dan keluarganya, sesuai dengan keahlian yang diperoleh pada masa kuliah.

Dalam hal ini kualitas seorang mahasiswa ketika lulus terlihat dari pencapaian hasil belajar yang diperolehnya semasa kuliah. Namun faktanya tidak semua mahasiswa dapat menjadi lulusan yang berkualitas. Ada beberapa faktor yang mempengaruhi hasil belajar, kemampuan pedagogik dan professional dosen sebagai pengajar juga menjadi faktor penentu keberhasilan dalam pembelajaran. Menurut Farida Sarimaya, kemampuan pedagogik meliputi "pemahaman terhadap peserta didik, perencanaan dan pelaksanaan pembelajaran, serta evaluasi prestasi belajar". Salah satu kompetensi pedagogik pengajar adalah mengelola proses pembelajaran. Apabila ada dosen yang kurang mampu mengelola proses pembelajaran, sehingga proses perkuliahan menjadi tidak menarik.

Sejalan dengan hal tersebut faktor yang mempengaruhi hasil belajar, sebagaimana yang diungkap oleh Muhibbin tentang faktor-faktor yang mempengaruhi hasil belajar berikut ini: Hasil belajar sangat dipengaruhi oleh beberapa faktor, seperti faktor eksternal dan faktor internal. Faktor eksternal diantarnya latar belakang keluarga, sekolah dan masyarakat, sedangkan faktor internal yaitu faktor fisiologi dan faktor psikologis. Faktor fisiologis merupakan kondisi umum jasmani seseorang, dan faktor psikologis merupakan faktor 
internal yang berpengaruh dari dalam diri mahasiswa dalam proses belajar diantaranya adalah minat. ${ }^{5}$

Minat belajar merupakan salah satu faktor penting dalam keberhasilan pembelajaran. Minat adalah kecenderungan yang tetap untuk memerhatikan dan mengenang beberapa kegiatan. Kegiatan yang diminati seseorang dan diperhatikan terus-menerus disertai dengan rasa senang.

Minat belajar perlu mendapatkan perhatian khusus karena minat belajar merupakan salah satu faktor penunjang keberhasilan proses belajar.Di samping itu, minat yang timbul dari kebutuhan mahasiswa merupakan faktor yang sangat penting bagi siswa dalam melaksanakan kegiatan-kegiatan atau usahausahanya. Anak akan belajar dengan baik apabila mempunyai minat belajar yang besar. Jika memiliki keinginan untuk belajar yang tinggi, ia akan cepat mengingat dan mengerti apa yang ia pelajari.

Mahasiswa dengan minat yang tinggi pada suatu mata kuliah tertentu akan mendorong dirinya untuk mengetahui secara mendalam materi pelajaran yang didapatnya. Mahasiswa yang memiliki minat tinggi terhadap pelajaran Pendidikan Agama Islam, sudah tentu akan selalu berupaya untuk memperbaiki hasil belajarnya. Mahasiswa tersebut akan aktif bertanya jika menemukan kesulitan dalam memahami pelajaran Pendidikan Agama Islam. Sebaliknya, seorang mahasiswa yang memiliki minat yang rendah pada mata kuliah Pendidikan Agama Islam, akan mengikuti proses kegiatan belajar dengan kurang aktif dan akan berdampak pada hasil belajar yang diperolehnya.

Dengan demikian, mahasiswa dengan minat belajar yang tinggi akan mencapai hasil belajar yang lebih baik daripada mahasiswa yang minat belajarnya rendah. Mahasiswa yang memiliki minat belajar yang tinggi akan mencurahkan perhatiannya secara maksimal. Dengan demikian, minat dapat diekspresikan melalui suatu pernyataan yang menunjukkan bahwa mahasiswa lebih menyukai suatu hal daripada lainnya.

Seseorang yang belajar dengan penuh minat, ia akan berusaha untuk belajar dengan penuh perhatian dan semangat belajar yang tinggi, serta senantiasa memotivasi dirinya untuk tertarik pada materi yang dipelajarinya, sehingga prestasi belajar meningkat. Jika kita menyimak kenyataan yang dihadapi dunia pendidikan pada umumnya dan khususnya di LP3I Kampus Depok, masih terdapat kecenderungan bahwa pendidikan belum sepenuhnya dapat membantu perkembangan kualitas mahasiswa secara optimal. Hal itu berdampak pada hasil belajar mahasiswa, salah satunya terlihat dari prestasi belajar Pendidikan Agama Islam yang belum optimal. Menurut dosen Pendidikan Agama Islam di LP3I ibu Yunianti saat Ujian Tengah Semester (UTS) ada beberapa mahasiswa yang mendapatkan nilai di bawah 70 bahkan ada beberapa mahasiswa yang mendapatkan nilai 40. Gejala perilaku mahasiswa

${ }^{5}$ Muhibbin Syah, Psikologi Pendidikan, Bandung: PT.Remaja Rosdakarya, 2010, Cet.XV, hlm. 130-132. 
dalam aktivitas belajar masih ada mahasiswa yang suka membolos, mengerjakan tugas dengan tidak teratur, sering tidak tepat waktu dalam menyelesaikan tugas, dan tampak enggan berusaha untuk mencapai hasil belajar yang lebih baik.

Gejala-gejala yang diperlihatkan oleh mahasiswa-mahasiswa tersebut dapat disebabkan oleh berbagai faktor, yaitu faktor-faktor yang berasal dari dalam diri mahasiswa dan faktor-faktor yang berasal dari luar dirinya. Kedua faktor itu dapat berpengaruh terhadap prestasi belajar mahasiswa.

Dengan latar belakang yang telah disebutkan di atas, maka peneliti tertarik untuk meneliti bagaimana kompetensi profesional dosen pendidikan agama islam dalam menghasilkan hasil belajar yang baik atau minimal para mahasiswa dapat menyelesaikan kuliah tepat waktu, dan apakah sejauh ini mahasiswa menganggap kompetensi dosen sangat berpengaruh dengan hasil prestasi atau malah sebaliknya dan penelitian ini juga akan meneliti bagaimana minat belajar mahasiswa dalam mengikuti perkuliahan apakah sudah mencapai hasil belajar atau prestasi yang memuaskan atau sebaliknya. Maka dari itu peneliti tertarik untuk meneliti tentang Pengaruh Kompetensi Profesional Dosen Agama Islam dan Minat Belajar terhadap Hasil Belajar Pendidikan Agama Islam Mahasiswa LP3I Kota Depok.

\section{B. METODE}

Penelitian dapat dilakukan dengan menggunakan berbagai macam metode dan sejalan dengan rancangan penelitian yang ada. Keputusan mengenai rancangan yang akan dipakai tergantung kepada tujuan penelitian, sifat permasalahan yang akan diteliti dan berbagai alternatif kemungkinan yang dapat digunakan. Sedangkan metode pada dasarnya cara atau jalan yang dipergunakan untuk mencapai suatu tujuan tertentu. Dalam hubungannya dengan penelitian ini maksud dari metode adalah cara atau jalan yang dipergunakan dengan tujuan untuk mencapai tujuan penelitian.

Metode Penelitian dalam pengertian yang luas dapat diartikan sebagai cara ilmiah, untuk mendapatkan data dengan tujuan dan kegunaan tertentu. Sugiyono $^{6}$ mengemukakan bahwa ada empat kata kunci yang perlu diperhatikan dalam menjelaskan metode penelitian, yaitu: cara ilmiah yang berarti kegiatan penelitian itu dilakukan berdasarkan pada karakteristik keilmuan, yakni rasional, emparis dan sistematis. Rasional yang berarti kegiatan penelitian itu dilakukan dengan cara-cara yang masuk akal, sehingga terjangkau oleh penalaran manusia. Empiris, yakni cara-caraa yang dilakukan dalam penelitian dapat diamati oleh indera manusia, sehingga orang lain dapat mengamati dan mengetahui cara-cara yang digunakan. Sistematis, artinya proses yang digunakan dalam penelitian ini menggunakan langkah-langkah tertentu yang bersifat logis. Walaupun langkah-langkah penelitian antara metode 
kuantitatif, kualitatif dan Research and Developement (RED) berbeda, akan tetapi seluruhnya sistematis.

Berdasarkan uraian di atas, maka yang dimaksud metode penelitian adalah suatu proses ilmiah dalam rangka mendapatkan data dan informasi yang valid dengan tujuan untuk menemukan, mengembangkan dan membuktikan suatu hipotesis atau ilmu pengetahuan tertentu, sehingga dapat digunakan untuk memahami, memecahkan, dan mengantisipasi masalah dalam bidang tertentu.

Menilik uraian di atas, dan sesuai tingkat kealamiahan tempat penelitian, maka metode dalam penelitian ini mengunakan metode survai dengan pendekatan korelasional. Metode survai dipergunakan dengan pertimbanganpertimbangan bahwa penelitian dilakukan untuk mendapatkan data setiap variabel masalah penelitian dari tempat tertentu yang alamiah (bukan buatan) dengan alat pengumpul data berbentuk angket (kuesioner), test dan wawancara terstruktur dan berdasarkan pandangan dari sumber data, bukan dari peneliti.

Populasi adalah wilayah generalisasi yang terdiri atas objek/subjek penelitian yang memiliki kualitas dan karakteristik tertentu yang ditetapkan oleh peneliti untuk dipelajari dan kemudian ditarik kesimpulan. ${ }^{7}$ Populasi dapat berupa manusia, hewan, tumbuh-tumbuhan, udara, gejala, nilai, peristiwa, sikap hidup, dan objek-objek lainya, yang dapat menjadi sumber data penelitian. Adapun populasi target dalam penelitian ini adalah seluruh mahasiswa LP3I Jakarta Kampus Depok pada semester 2.

\section{HASIL DAN PEMBAHASAN}

Berdasarkan hasil pengujian hipotesis sebagaimana telah diuaraikan di atas, maka secara keseluruhan temuan dalam penelitian ini, dapat dibahas dengan cara mengkonfirmasi terhadap teori-teori yang sudah ada, sebagaimana telah dikemukakan pada Bab II, jadi dalam pembahasan penelitian ini akan diuraikan hasil temuan penelitian dan menguraikan hasil uji hipotesis berserta teori-teori yang telah diungkapkan sebelumnya.

Dari hasil analisis deskriptif variabel penelitian variabel Hasil Belajar dilihat dari skor rata-rata Hasil Belajar yaitu 60,77 atau sama 60,77:150 X 100\%= $40,52 \%$ dari skor idealnya yaitu 150. Data ini dapat ditafsirkan sebagai tingkat atau taraf perkembangan variabel tersebut dengan kriteria sebagai berikut. Pada kreteria taraf sangat rendah sebesar 40,52 \%, Hal ini menunjukkan bahwa Pentingnya meningkatkan Hasil Belajar disuatu lembaga pendidikan, sehingga Hasil Belajar disuatu lembaga pendidikan sesuai yang diharapkan oleh kampus. Untuk variabel kompetensi professional di lihat dari skor rata-rata yaitu 98,72 atau sama dengan $98,72: 150 \times 100 \%=65,82 \%$ dari skor idealnya 150 , pada kriteria taraf rendah sebesar 65,82 \%. Hal ini menunjukkan bahwa pentingnya meningkatkan kompetensi profesional yang ada pada diri dosen di suatu pendidikan tinggi sesuai yang di harapkan oleh kampus. Sedangkan variabel

7Sugiyono, Metode Penelitian Pendidikan Pendekatan Kuantitatif, Kualitatif, dan R E D, h.117 
minat belajar dilihat dari skor skor rata-rata minat Belajar yaitu 93,23 atau sama dengan $93,23: 150 \times 100 \%=62,16 \%$ dari skor idealnya yaitu 150, pada taraf sedang sebesar 62,16 \% Hal ini menunjukkan bahwa Pentingnya meningkatkan Minat Belajar pada diri seoorang Mahasiswa, sehingga dapat meningkatkan Hasil Belajar disuatu lembaga Pendidikan sesuai yang diharapkan oleh kampus LP3I Jakarta Kampus Depok.

Sedangkan hasil uji persyaratan hipotesis penelitian telah terpenuhi, yakni uji linieritas persamaan regresi $\hat{Y}$ atas $X_{1}$ dengan hasil $\mathrm{P}$ Sig $=0,803>0,05(5 \%)$ atau $F_{\text {hitung }}=0,703$ dan $F_{\text {tabel }}$ dengan dk pembilang 35 dan dk penyebut 24 dan pada taraf kepercayaan (signifikansi) $\alpha=0,05$ adalah 1.82 (F $\left.0,703<\mathrm{F}_{\text {tabel }} 1,82\right)$ berarti $\hat{Y}$ atas $\mathrm{X}_{1}$ adalah linear dan persamaan regresi $\mathrm{Y}$ atas $\mathrm{X}_{2}$ menunjukkan nilai $\mathrm{P}$ Sig $=0,22>0,05(5 \%)$ atau $F_{\text {hitung }}=2,120$ dan $F_{\text {tabel }}$ dengan dk pembilang $24 \mathrm{dan} \mathrm{dk}$ penyebut 35 dan pada taraf kepercayaan (signifikansi) $\quad \alpha=0,05$ adalah 1,65 (F $\left.F_{\text {hitung }} 2,120<F_{\text {tabel }} 1,96\right)$ yang berarti $\hat{Y}$ atas $X_{2}$ adalah linear. Sedangkan untuk uji normalitas persamaan regresi $\hat{Y}$ atas $\mathrm{X}_{1}$ dan $\mathrm{X}_{2}$ menunjukkan Asymp. Sig (2-tailed) atau nilai $\mathrm{P}=0,200>0,05$ (5\%) atau $Z_{\text {hitung }} 0.087$ dan $Z_{\text {tabel }}$ pada taraf kepercayaan/signifikansi $\alpha=0,05$ adalah

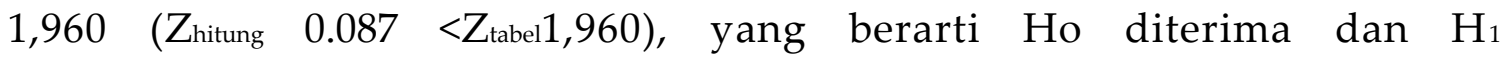
ditolak.Dengan demikian dapat diinterpretasikan atau ditafsirkan bahwa persyaratan normalitas distribusi galat taksiran terpenuhi dengan kata lain galat taksiran persamaan regresi $\hat{Y}$ atas $\mathrm{X}_{1} \mathrm{X}_{2}$ adalah berdistribusi normal.

Untuk selanjutnya akan menguraikan hasil uji hipotesis berserta teoriteori yang telah diungkapkan sebelumnya.

Pertama, hasil penelitian ini sejalan dengan teori kompetensi profesional yang dikemukakan oleh E.Mulyasa dan Kompetensi Profesional adalah seperangkat pengetahuan, keterampilan, dan perilaku yang harus dimiliki, dihayati, dan dikuasai oleh guru atau dosen dalam melaksanakan tugas keprofesionalan. ${ }^{8}$ Muhibbin Syah mengemukakan bahwa kompetensi adalah kemampuan atau kecakapan. ${ }^{9}$ Kompetensi profesional dalam pandangan islam merupakan terpenting dalam islam, karena islam bukan hanya agama yang mengajarkan ibadah dalam artian formal melainkan juga mengajarkan ummatnya untuk melakukan pekerjaan secara profesional. Hal itu tergolong dalam kategori ibadah. Islam menyuruh ummatnya untuk melakukan suatu perkaran dengan sungguh-sungguh tidak asal-asalan sebagaiamana Nabi Muhammad Saw pun dahulu melakukan misi kerasulanya dengan

8 Departemen Agama RI, Kumpulan Undang-Undang dan Peraturan Pemerintah RI tentang Pendidikan (Jakarta: Dirjen Pendidikan Islam Departemen Agama RI, 2007), hlm.. 74.

${ }_{9}$ Muhibbin Syah, Psikologi Pendidikan dengan Pendekatan Baru, Bandung: PT. Remaja Rosdakarya, 2000, hlm. 229. 
menyampakan ajaran Islam kepada ummatnya secara sungguh-sungguh dan penuh perjuangan serta pengorbanan. ${ }^{10}$

Pekerjaan atau profesi menurut islam harus dilakukan karena Allah. "Karena Allah" maksudnya ialah karena diperintahkan Allah. Jadi, profesi dalam islam harus dijalani karena merasa bahwa itu adalah perintah Allah. Dalam kenyataannya pekerjaan itu dilakukan untuk orang lain, tetapi niat yang mendasarinya adalah perintah Allah. Dari sini kita mengetahui bahwa pekerjaaan profesi di dalam islam dilakukan untuk atau sebagai pengabdian kepada dua objek, yaitu: pengabdian kepada Allah dan sebagai pengabdian atau dedikasi kepada manusia atau kepada yang lain sebagai objek pekerjaaan itu. Jelas pula bahwa kriteria "pengabdian" dalam islam lebih kuat dan lebih mendalam dibandingkan dengan pengabdian dalam kriteria yang diajarkan diatas tadi. Pengabdian dalam islam, selain demi kemanusiaan, juga dikerjakan demi Tuhan, jadi unsur transenden ini dapat menjadikan pengalaman profesi dalam islam lebih tinggi nilai pengabdiannya dibandingkan dengan pengalaman profesi yang tidak didasari oleh keyakian iman kepada Tuhan.

Setelah diperhatikan dan ditelaah dari berbagai sumber yang sudah dicantumkan suatu hal yang menjadi dasar suatu pekerjaan seseorang ialah secara sungguh-sungguh dan bertanggung jawab karena adanya keikhlasan didalam niat. Betapapun ringannya suatu pekerjaan apabila tidak dilakukan dengan niat yang ikhlas maka hanya akan menjadi beban. Akan tetapi dengan niat yang ikhlas maka akan muncul sifat profesionalisme pada diri seorang guru untuk menjalankan profesinya. Berkenaan dalam hal itu Allah Swt berfirman di dalam Al-Qur'an Surat Al-Bayyinah ayat 5.

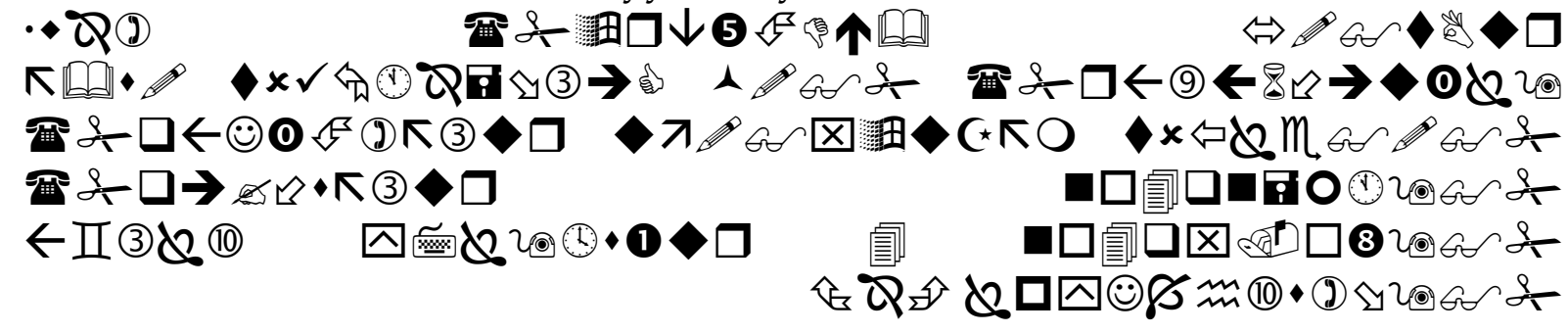

"Padahal mereka tidak disuruh kecuali supaya menyembah Allah dengan memurnikan ketaatan kepada-Nya dalam (menjalankan) agama yang lurus, dan supaya mereka mendirikan shalat dan menunaikan zakat; dan yang demikian itu adalah agama yang

lurus."

Kalimat memurnikan ketaatan itulah disebut ikhlas, yaitu berbuat sesuatu dengan niat yang murni semata-mata untuk Allah Swt, manakala suatu aktivitas telah diniatkan maka akan muncul kesungguhan aktivitas itu dengan niat yang ikhlas dan berat bisa menjadi ringan dan sulitpun bisa menjadi mudah.

10Suheri Mukri, Korelasi Kompetensi Profesional Guru dan Perhatian oang tua terhadap Motivasi Belajar siswa, Jakarta: Tesis, 2012, hlm.44 
Sehingga seorang guru yang ikhlas akan menjadi mudah dalam mengatasi berbagai problem dalam proses belajar mengajarnya.

Didalam ayat ini terdapat kalimat hunafa yang artinya dengan lurus dalam tafsir ibnu Katsir dikatakan bahwa berlaku lurus adalah bertolak dari kemusrikan menuju ketauhidan. ${ }^{11}$ Isyarat Al-qur'an tentang pentingnya profesionalisme yang harus dimiliki oleh setiap orang baik seorang guru maupun dosen dan yang lainnya. Di dalam Al-qur'an Surat Annisa ayat 58 Allah menyatakan.

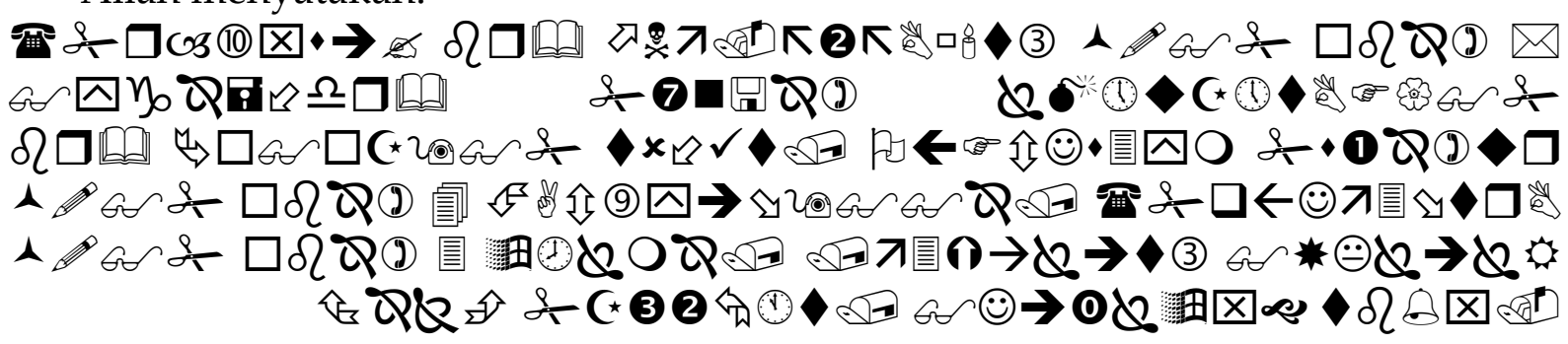

"Sesungguhnya Allah menyuruh kamu menyampaikan amanat kepada yang berhak menerimanya, dan (menyuruh kamu) apabila menetapkan hukum di antara manusia supaya kamu menetapkan dengan adil. Sesungguhnya Allah memberi pengajaran yang sebaik-baiknya kepadamu. Sesungguhnya Allah adalah Maha mendengar lagi Maha melihat."

Kedua, hasil penelitian ini mendukung teori Sabri M, Alisuf indikator mahasiswa yang memiliki minat belajar yang tinggi hal ini dapat dikenali melalui proses belajar dikelas maupun dirumah yaitu:

1. Perasaan Senang.

Seorang siswa yang memiliki perasaan senang atau suka dalam hal tertentu ia akan cinderung mengetahui antara perasaan dengan minat. Siswa yang berminat terhadap asuhan kebidanan maka ia akan rajin dan terus menerus membaca dan mempelajari semua ilmu yang berhubungan dengan asuhan kebidanan.

2. Giat Belajar.

Aktifitas atau giat belajar di luar kelas merupakan indikator yang dapat menunjukan keberadaan minat pada diri mahasiswa.mahasiswa dengan minat tinggi, akan merasa bahwa pelajaran yang diberikan di kelas sangatlah terbatas waktunya, sehingga ia perlu untuk mencari pengetahuan lain di luar jam pelajaran.

3. Mengerjakan Tugas.

Kebiasaan mengerjakan tugas yang diberikan dosen merupakan salah satu indikator yang menunjukan minat mahasiswa.Tugas yang diberikan dosen bertujuan untuk memperdalam kemampuan mahasiswa. Mahasiswa yang

${ }_{11}$ Abu Al-Fida Ismail bin Katsir Al-Quraysiyyi Ad-Dimasqi, tafsir Al-qur'an Al-adzim Jilid 4, Beirut: Daar Fikr, 1992, hlm. 537. 
memiliki minat yang tinggi akan menyadari pentingnya melaksanakan tugas-tugas dari dosen ia lebih menguasai materi dengan baik.

4. Perhatian Dalam Belajar.

Adanya perhatian juga menjadi salah satu indikator minat. Perhatian merupakan konsentrasi atau aktifitas jiwa kita terhadap pengamatan,pengertian, dan sebagainya dengan mengesampingkan yang lain dari pada itu. Seseorang yang memiliki minat pada objek tertentu maka dengan sendirinya dia akan memperhatikan objek tersebut. ${ }^{12}$

5. Mengetahui Tujuan Belajar.

Belajar adalah suatau aktifitas yang bertujuan.Tujuan belajar ini ada yang benar-benar disadari dan ada juga yang kurang disadari oleh mahasiswa.Tujuan belajar tersebut eratkaitannya dengan perubahan atau pembentukan tingkah laku tertentu.mahasiswa yang menyadari akan pentingnya tujuan belajar, maka siswa tersebut akan giat dalam mengikuti mata kuliah dikelas. ${ }^{13}$

Minat pada dasarnya adalah penerimaan akan suatu hubungan antara diri sendiri dengan sesuatu di luar diri. Semakin kuat atau dekat hubungan tersebut, semakin besar minat". ${ }^{14}$ Minat yang ada pada manusia memberikan kemudahan dalam mendapatkan yang diinginkan, sesuai dengan Firman Allah SWT dalam surat An-Najm ayat 39 yang berbunyi:

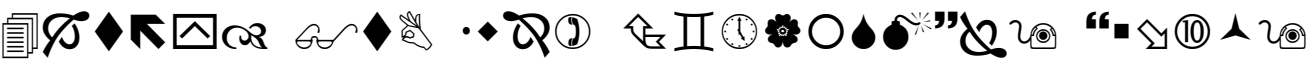

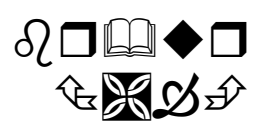

"Dan bahwasanya seorang manusia tiada memperoleh selain apa yang telah diusahakannya."(QS. An-Najm :39-40)."

\section{KESIMPULAN}

Berdasarkan hasil penelitian pada jurnal ini dapat disimpulkan hasil belajar mahasiswa disuatu lembaga pendidikan sangat diharuskan di atas KKM karena sebagai perbaikan sistem pendidikan yang ada di lembaga pendidikan tersebut dan untuk kebaikan diri mahasiswa. Banyak faktor-faktor yang memepengaruhi hasil belajar mahasiswa. Oleh karena itu pada penelitian ini lebih memfokuskan pada kompetensi profesional serta minat belajar sehingga dapat mempengaruhi hasil belajar mahasiswa. Dalam hal ini di buktikan dengan hasil penelitian yang menyebutkan bahwa :

${ }^{12} \mathrm{Abd}$. Rachman Abror, Psykologi Pendidikan, Yogyakarta: PT.Tiara Wacana, 2003, hal. 56.

${ }^{13}$ Sabri M, Alisuf, Psikologi Pendidikan Cet. Ke-11. Jakarta: Pedoman Ilmu Jaya, 2005, hlm 45.

${ }^{14}$ Slameto, Belajar dan Faktor-faktor yang Mempengaruhinya, Jakarta: Rineka Cipta, 2003, hlm. 
Penelitian ini bertujuan untuk mengetahui dan menguji data-data empirik terkait dengan Kompetensi Profesional Dosen dan Minat Belajar terhadap pHasil Belajar secara terpisah maupun simultan. Dalam penelitian ini penulis menggunakan metode survei,dengan teknik korelasional dan analisis regresi sederhana dan ganda. Sampel penelitian ini adalah sebanyak 60 responden atau menggunakan seluruh jumlah populasi mahasiwa LP3I Jakarta Kmapus Depok semester 2. Teknik pengumpulan data menggunakan angket, observasi, dan studidokumenter. Teknik analisa data yang digunakan model analisis Deskriptif, koefisien korelasi, analisis regresi sederhana dan regresi ganda. Jenis analisis yang digunakan adalah analisa korelasi dan regresi sederhana dan regresi ganda yang dijabarkan secara deskriptif. Hasil penelitian ini menunjukkan bahwa:

Pertama, terdapat pengaruh positif dan signifikan Kompetensi Profesional Dosen terhadap Hasil Belajar di LP3I Jakarta Kampus Depok. Hal ini dibuktikan dengan hasil nilai koefisien korelasi (r) variabel Kompetensi Profesional Dosen ( $\left.\mathrm{X}_{1}\right)$ dengan variabel Hasil Belajar (Y) di peroleh nilai Pearson correlation (ry1) sebesar 0,394 dan koefisien determinasi $\mathrm{R}^{2}(R$ square) sebesar 0,155. Sedangkan hasil analisis regresi sederhana, menunjukkan persamaan regresi (unstandardized coefficients $B$ ) $\hat{Y}=23,327+0,379 X_{1}$, yang berartibahwasetiappeningkatansatu unit skor Kompetensi Profesional akan mempengaruhi Hasil Belajar sebesar 0,379.

Kedua, terdapat pengaruh positif dan signifikan Minat belajar terhadap Hasil Belajar di LP3I Jakarta Kampus Depok. Hal ini dibuktikan dengan hasil nilai koefisien variabel Minat belajar $\left(\mathrm{X}_{2}\right)$ dengan Hasil Belajar $(\mathrm{Y})$ diperoleh nilai Pearson correlation (ry2) sebesar 0,342 dan koefisien determinasi $\mathrm{R}^{2}(R$ square) sebesar 0,117. Sedangkan hasil analisis regresi sederhana, menunjukkan persamaan regresi (unstandardized coefficients $B$ ) $\hat{Y}=21,548+0,421 \mathrm{X}_{2}$, yang berarti bahwa setiap peningkatan satu unit minat belajar akan mempengaruhi peningkatan skor hasil belajar sebesar 0,421.

Ketiga, terdapat pengaruh positif dan signifikan antara Kompetensi Belajar dan minat belajar secara bersama-sama terhadap Hasil Belajar di kampus LP3I Jakarta Kampus Depok. Hal ini di buktikan dengan besarnya pengaruh yang dapat dilihat dari hasil koefisien determinasi $R^{2}(R$ square) sebesar 0,410 dan hasil analisis regresi ganda yang dilakukan secara bersama, menunjukkan persamaan regresi (unstandardized coefficients $B$ ) $\hat{Y}=36,437+0,187 X_{1}+0,285 X_{2}$ serta hasil uji koefisien korelasi parsial yang menunjukkan $\left(\mathrm{r}_{1.2}\right)=0,301$ dan $\mathrm{p}$-value $=0,00<$ 0,05 dan $\left(\mathrm{r}_{2.1}\right)=0,168$ dan $\mathrm{p}$-value $=0,020<0,05$ yang berarti signifikan. Maka dapat disimpulkan bahwa setiap peningkatan satu unit skor Kompetensi Profesional dan Minat belajar akan mempengaruhi prestasi akademik sebesar 0,285 . 


\section{DAFTAR PUSTAKA}

Abd. Rachman Abror, Psykologi Pendidikan, Yogyakarta: PT.Tiara Wacana, 2003.

Abu Al-Fida Ismail bin Katsir Al-Quraysiyyi Ad-Dimasqi, tafsir Al-qur'an Al-adzim Jilid 4, Beirut: Daar Fikr, 1992.

Departemen Agama RI, Kumpulan Undang-Undang dan Peraturan Pemerintah RI tentang Pendidikan Jakarta: Dirjen Pendidikan Islam Departemen Agama RI, 2007.

Jamal Ma`mur Asmani, 7 Kompetisi Guru Menyenangkan dan Profesional, Yogyakarta: Power Books, 2009.

Muhibbin Syah, Psikologi Pendidikan dengan Pendekatan Baru, Bandung: PT. Remaja Rosdakarya, 2000.

Muhibbin Syah, Psikologi Pendidikan, Bandung: PT.Remaja Rosdakarya, 2010, Cet.XV.

Muhibbin Syah, Psikologi Pendidikan dengan Pendekatan Baru , Bandung: PT. Remaja Rosdakarya, 2000.

Oemar Hamalik, Kurikulum dan Pembelajaran, Jakarta: Bumi Aksara, 2009.

Sabri M, Alisuf, Psikologi Pendidikan Cet. Ke-11. Jakarta: Pedoman Ilmu Jaya, 2005.

Slameto, Belajar dan Faktor-faktor yang Mempengaruhinya, Jakarta: Rineka Cipta, 2003

Suheri Mukri, Korelasi Kompetensi Profesional Guru dan Perhatian oang tua terhadap Motivasi Belajar siswa, Jakarta: Tesis, 2012.

Sugiyono, Metode Penelitian Pendidikan Pendekatan Kuantitatif, Kualitatif, dan $R \mathcal{E} D$, h.117

Timur Djaelani, Kebijaksanaan Pembinaan Kelembagaan Agama Islam, Jakarta: Darma Bhakti, 1983.

Undang-undang Sisdiknas Sistem Pendidikan Nasional, Jakarta: Sinar Grafika, 2003. 